Supporting Information

\title{
Solid-Phase Detoxification of Chemical Warfare Agents using Zirconium-based Metal Organic Frameworks and the Moisture Effects: Analyzed via Digestion
}

Hui Wang, *John J. Mahle, Trenton M. Tovar, Gregory W. Peterson, Morgan G. Hall, Jared B.

DeCoste, James H. Buchanan, and Christopher J. Karwacki*

U.S. Army Combat Capabilities Development Command Chemical Biological Center, 8198

Blackhawk Road, Aberdeen Proving Ground, MD 21010, United States

*Corresponding Authors: hui.wang7.civ@mail.mil; christopher.j.karwacki.civ@mail.mil 
Section S1. $\mathrm{N}_{2}$ Isotherms, SEM Images, PXRD and TGA of UiO-66, UiO-66-NH $\mathrm{N}_{2}$ and NU-1000
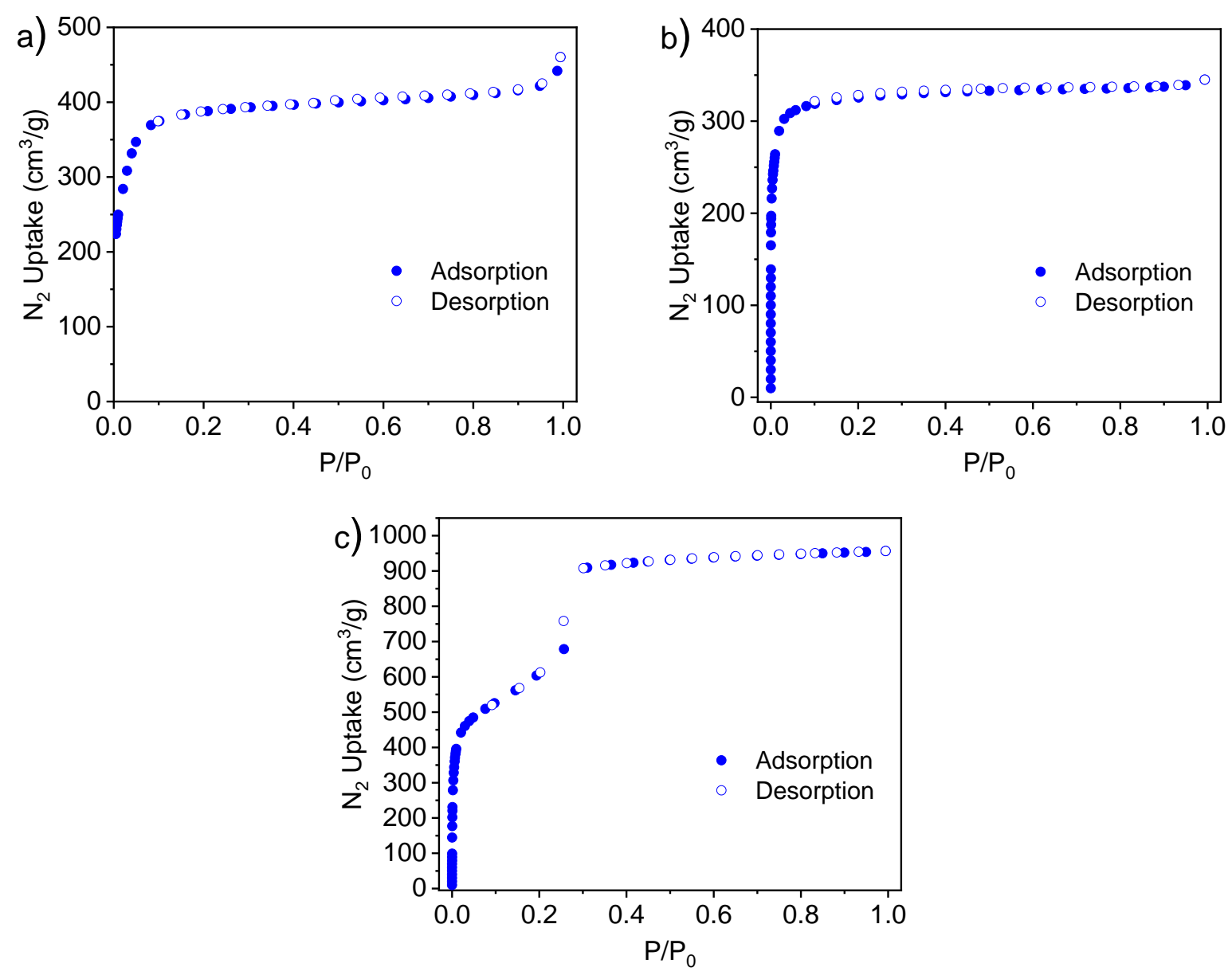

Figure S1. $\mathrm{N}_{2}$ isotherms of a) UiO-66, b) UiO-66- $\mathrm{NH}_{2}$ and c) NU-1000 at 77K. BET surface areas of UiO66, UiO-66- $\mathrm{NH}_{2}$ and $\mathrm{NU}-1000$ are 1580,1300 , and $2100 \mathrm{~m}^{2} / \mathrm{g}$, respectively.
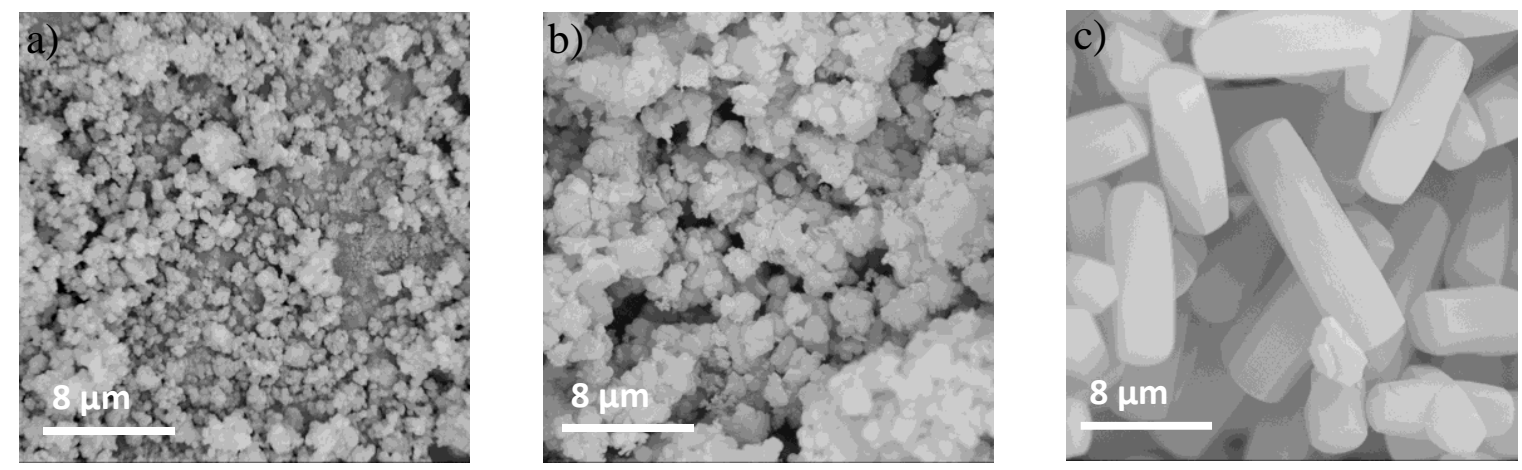

Figure S2. Scanning Electron Microscopy (SEM) images of a) UiO-66, b) UiO-66- $\mathrm{NH}_{2}$ and c) NU-1000. 

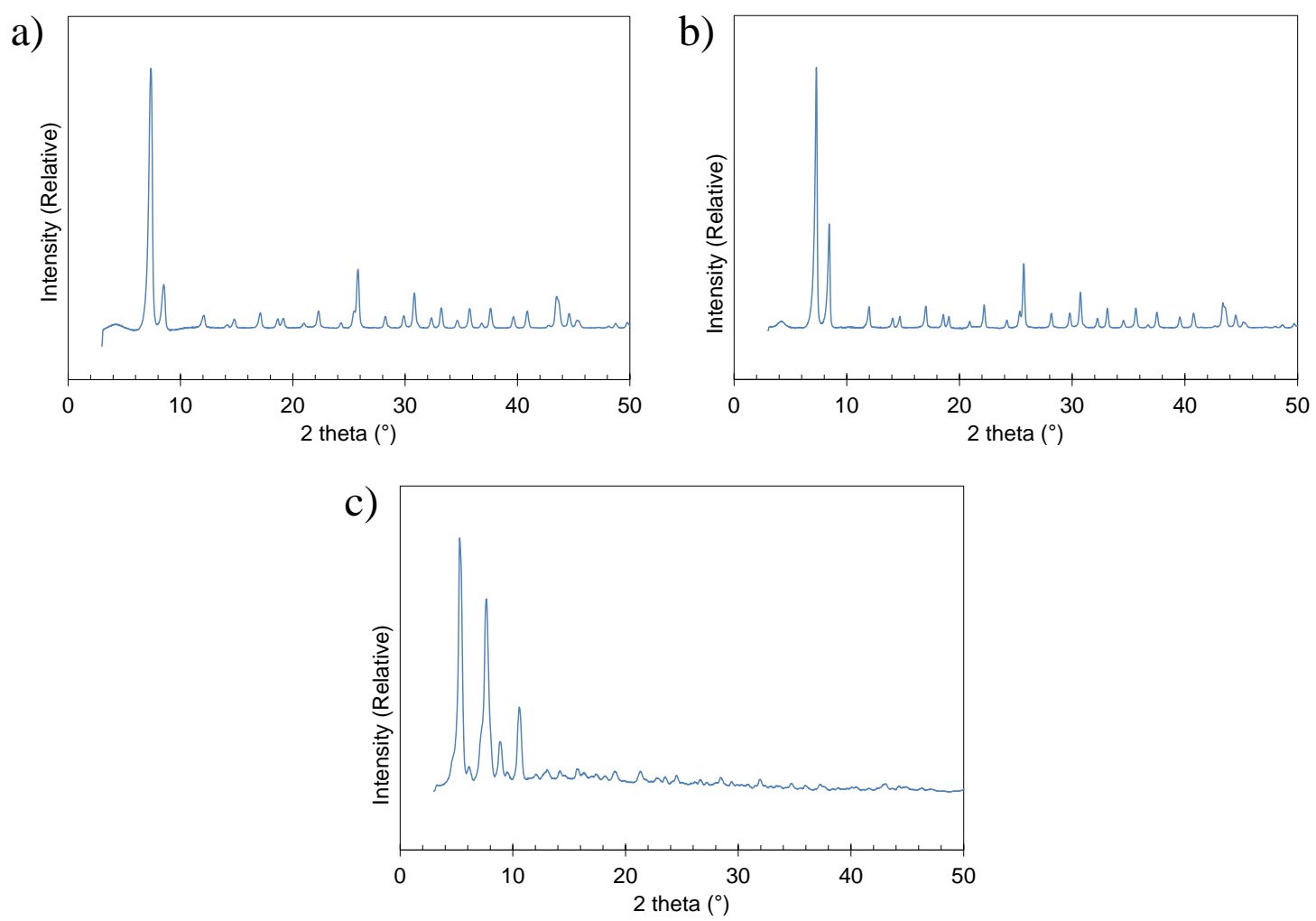

Figure S3. Powder X-ray Diffraction (PXRD) of a) UiO-66, b) UiO-66- $\mathrm{NH}_{2}$ and c) NU-1000.
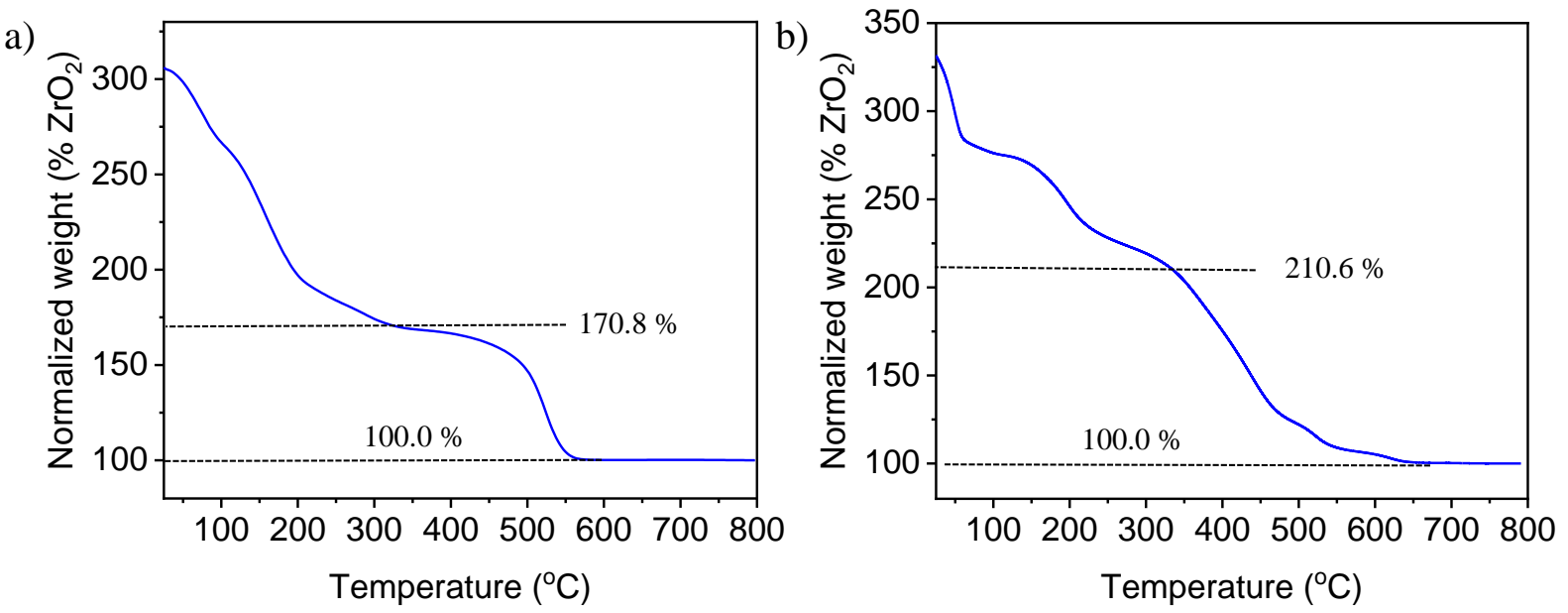

Figure S4. Thermalgravimetric analysis (TGA) of as-received a) UiO-66 and b) UiO-66- $\mathrm{NH}_{2}$. Defect calculation using TGA data according to a previously published procedure ${ }^{1}$ showed 7.1 and 10 out of 12 linkers present per node for $\mathrm{UiO}-66$ and $\mathrm{UiO}-66-\mathrm{NH}_{2}$, respectively. Note that defect calculation for UiO$66-\mathrm{NH}_{2}$ can be off due to lack of a clear plateau. 


\section{Section S2. Stabilities of DMNP and GD in Digestion Media}
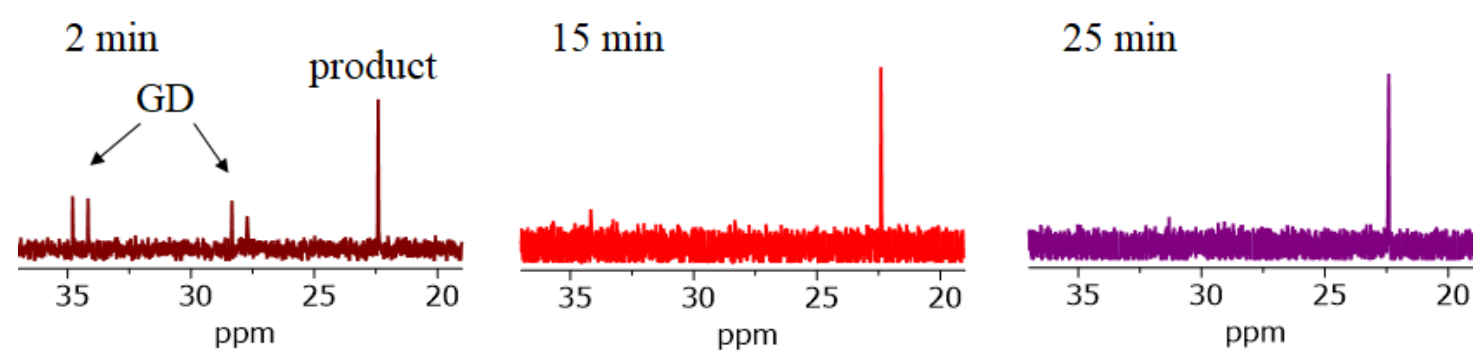

Figure S5. Selected ${ }^{31} \mathrm{P}$ NMR spectra of GD in $0.5 \mathrm{M} \mathrm{NaHCO}_{3}$ aqueous solution over time.

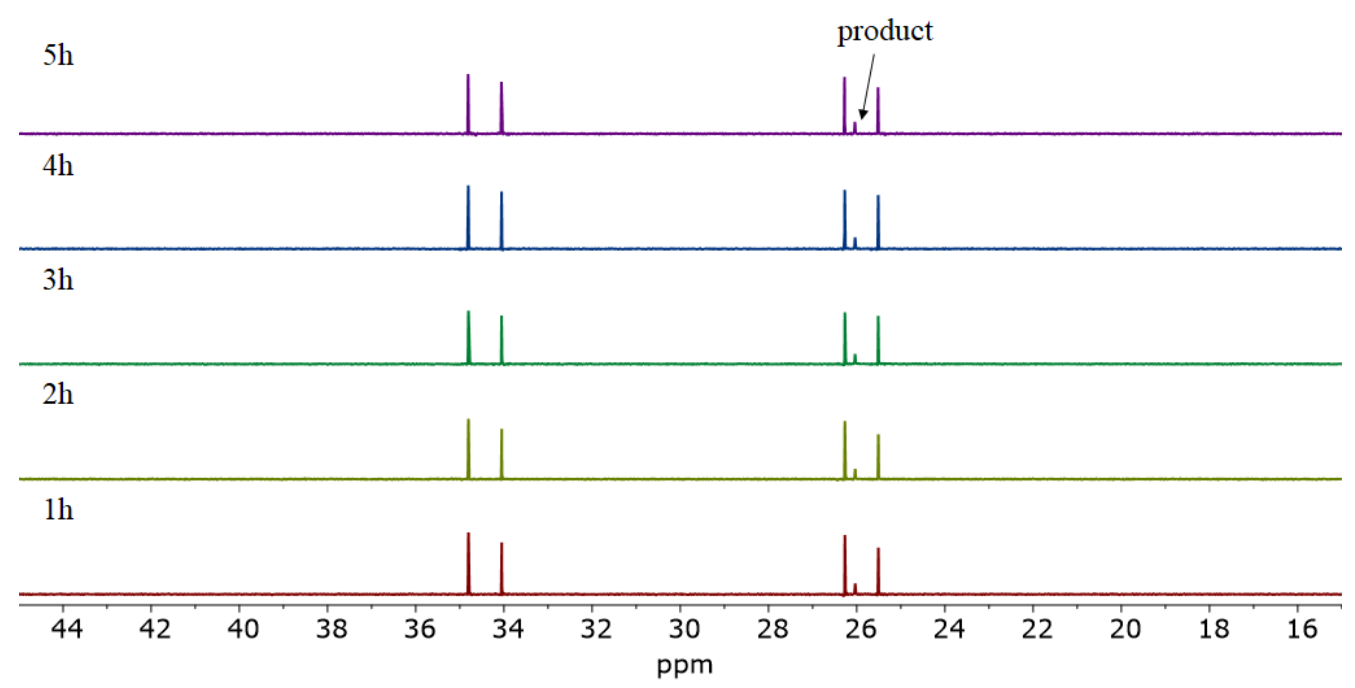

Figure S6. Selected ${ }^{31} \mathrm{P}$ NMR spectra of GD in HF/DMSO- $\mathrm{d}_{6}$ digestion medium over time. Note the product peak was present originally due to the purity of our GD ( 90\%). 

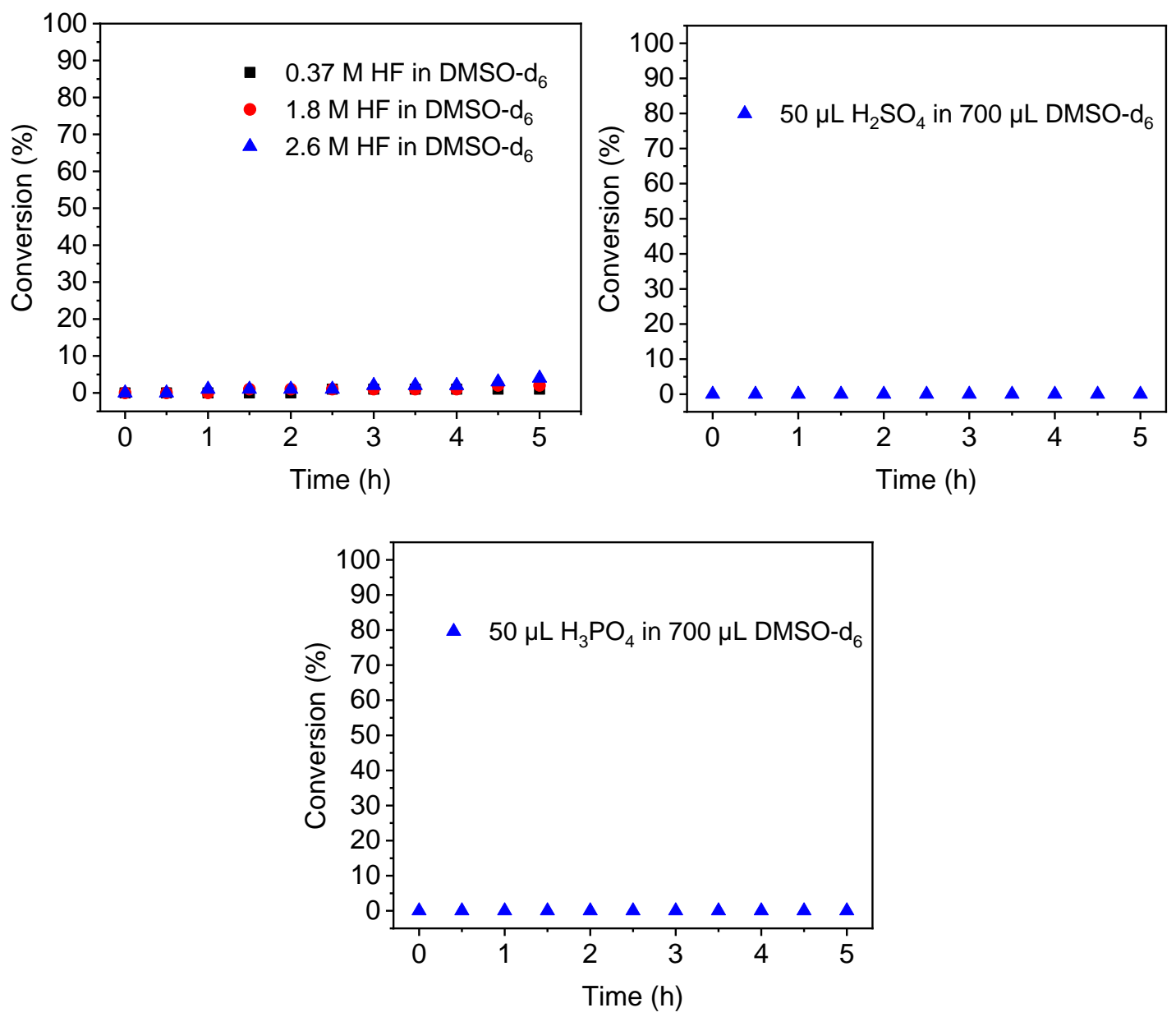

Figure S7. Conversion of DMNP over time in acidic digestion media.

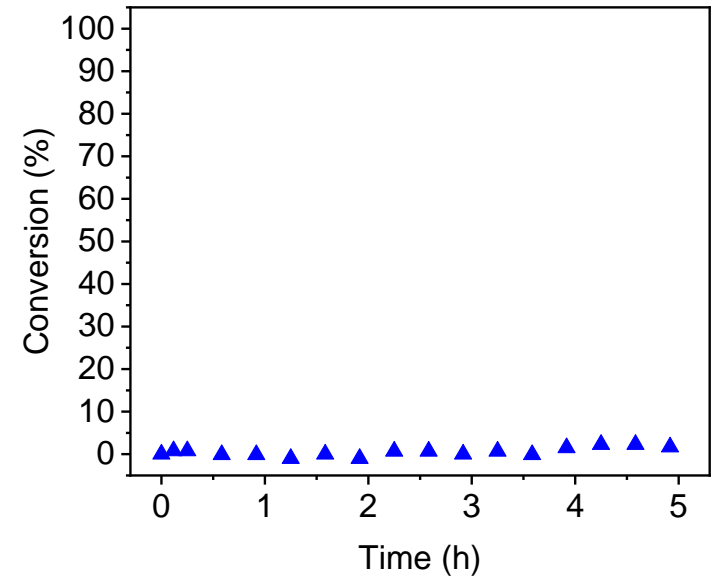

Figure S8. Conversion of VX over time in $1.8 \mathrm{M} \mathrm{HF}$ in DMSO-d $\mathrm{d}_{6}$. 
Section S3. Solid-Phase Decontamination of DMNP, GD and VX by UiO-66, UiO-66-NH 2 and NU1000.

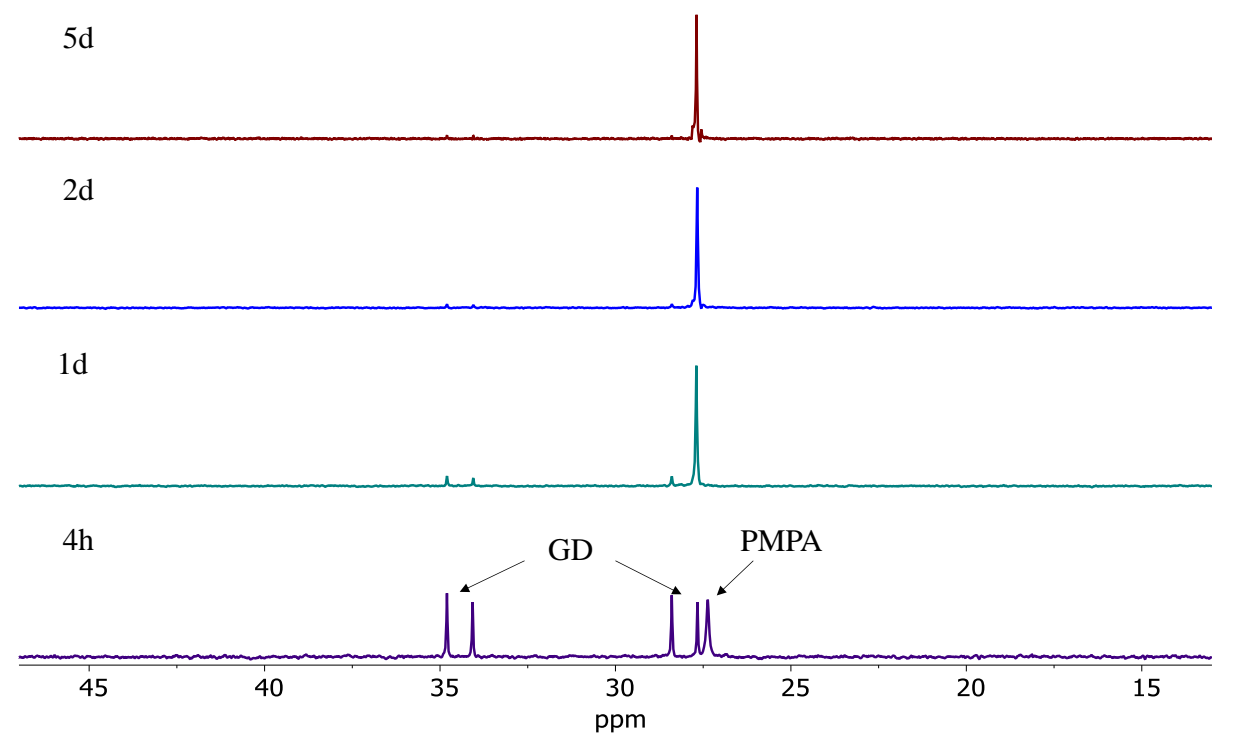

Figure S9. ${ }^{31} \mathrm{P}$ NMR spectra of solid-phase decontamination of GD by UiO-66- $\mathrm{NH}_{2}$ over time. Only the non-toxic pinacolyl methylphosphonic acid (PMPA) product was observed for all three MOFs. Spectra of UiO-66- $\mathrm{NH}_{2}$ were shown as an example.

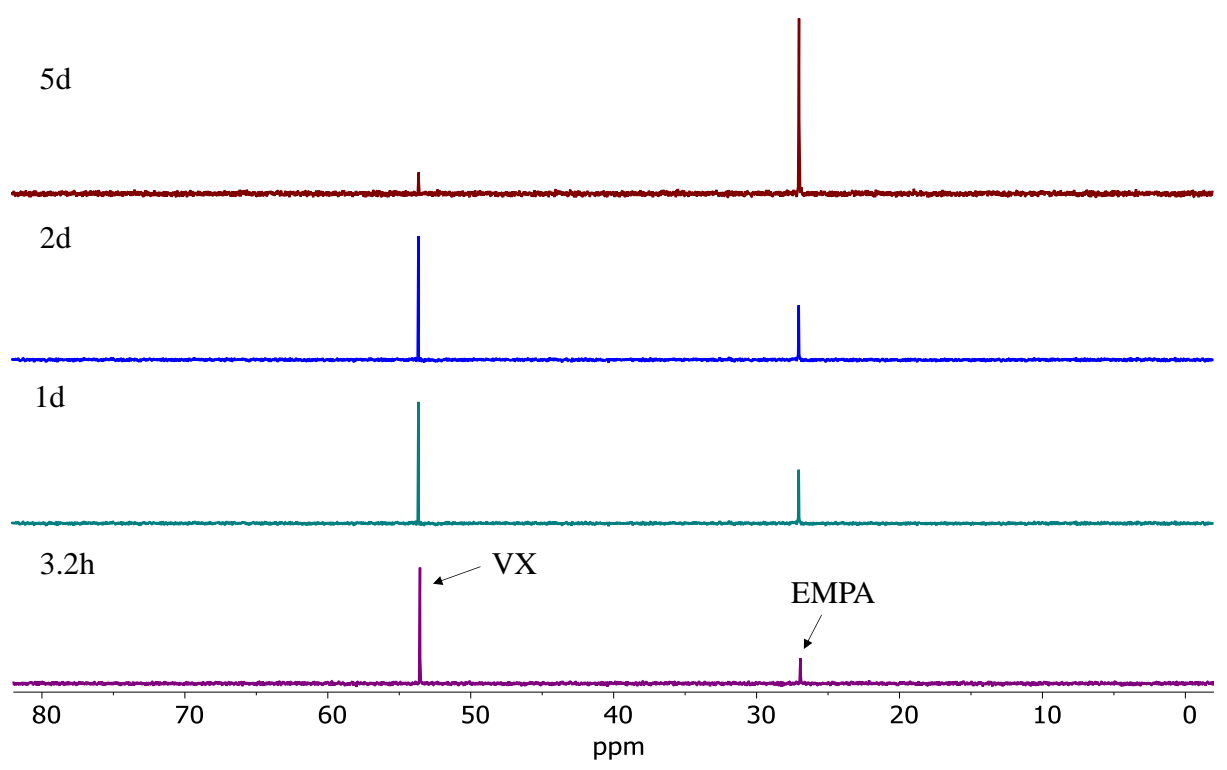

Figure S10. ${ }^{31} \mathrm{P}$ NMR spectra of solid-phase decontamination of VX by UiO-66- $\mathrm{NH}_{2}$ over time. Only the non-toxic ethyl methylphosphonic acid (EMPA) product was observed for all three MOFs. Spectra of UiO66- $\mathrm{NH}_{2}$ were shown as an example. 


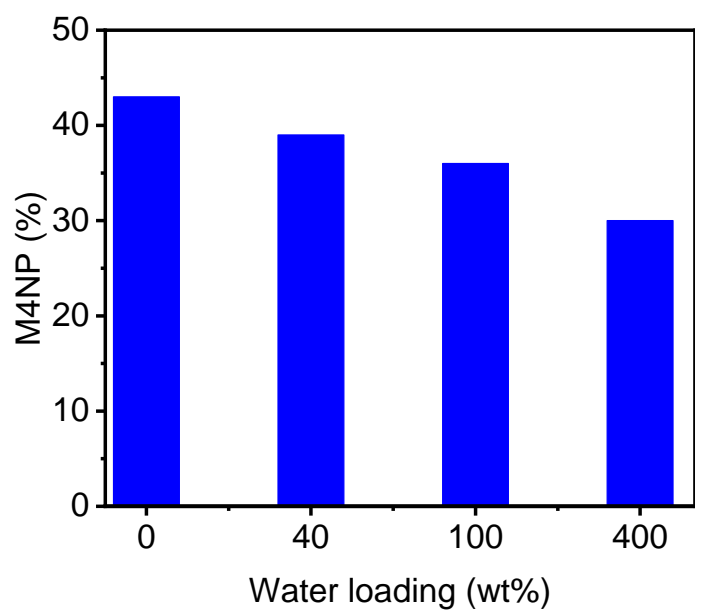

Figure S11. Percentage of M4NP generated as a decontamination product of DMNP by UiO-66- $\mathrm{NH}_{2}$ (incubated for $1 \mathrm{~d}$ ) as a function of water loading.

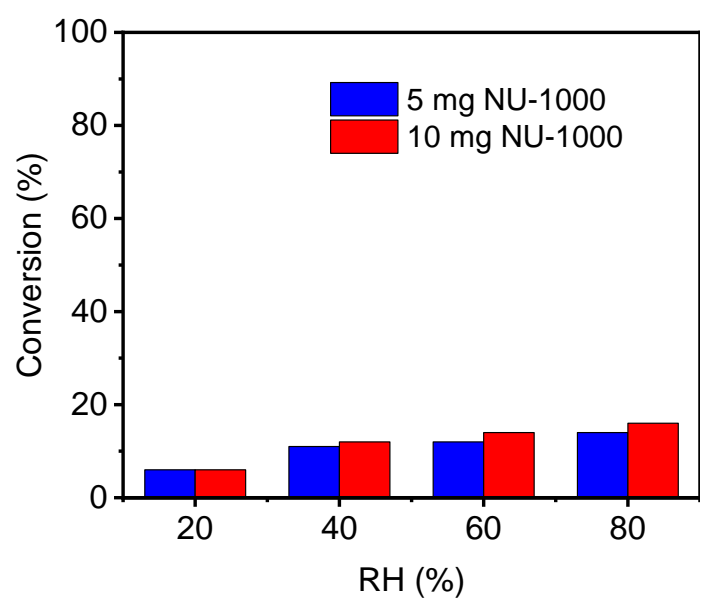

Figure S12. Conversion of DMNP $(1 \mu \mathrm{L})$ by NU-1000 (incubated for $1 \mathrm{~d}$ ) under different RH conditions. 
Table S1. The number of moles of catalyst active sites, adsorbed water, and DMNP used for solidphase decontamination of DMNP by UiO-66, UiO-66- $\mathrm{NH}_{2}$, and $\mathrm{NU}-1000$ under different $\mathrm{RH}$ conditions.

\begin{tabular}{|l|l|l|l|l|l|l|}
\hline & $\begin{array}{l}\text { Active } \\
\text { site } \\
(\mathrm{mmol})\end{array}$ & $\begin{array}{l}\text { DMNP } \\
(\mathrm{mmol})\end{array}$ & $\begin{array}{l}\mathrm{H}_{2} \mathrm{O} \\
(\mathrm{mmol}), \\
20 \% \mathrm{RH}\end{array}$ & $\begin{array}{l}\mathrm{H}_{2} \mathrm{O} \\
(\mathrm{mmol}), \\
40 \% \mathrm{RH}\end{array}$ & $\begin{array}{l}\mathrm{H}_{2} \mathrm{O} \\
(\mathrm{mmol}), \\
60 \% \mathrm{RH}\end{array}$ & $\begin{array}{l}\mathrm{H}_{2} \mathrm{O} \\
(\mathrm{mmol}), \\
80 \% \mathrm{RH}\end{array}$ \\
\hline UiO-66 $(5 \mathrm{mg})$ & 0.0171 & 0.0056 & 0.0127 & 0.113 & 0.131 & 0.140 \\
\hline UiO-66- $\mathrm{NH}_{2}(5 \mathrm{mg})$ & 0.0061 & 0.0056 & 0.0317 & 0.0738 & 0.0799 & 0.0846 \\
\hline NU-1000 $(5 \mathrm{mg})$ & 0.0092 & 0.0056 & 0.0126 & 0.0252 & 0.0667 & 0.414 \\
\hline NU-1000 $(10 \mathrm{mg})$ & 0.0184 & 0.0056 & 0.0252 & 0.0504 & 0.1334 & 0.828 \\
\hline
\end{tabular}

Table S2. The number of moles of catalyst active sites, adsorbed water, and DMNP used for solidphase decontamination of DMNP by UiO-66, UiO-66- $\mathrm{NH}_{2}$, and $\mathrm{NU}-1000$ with different water loadings.

\begin{tabular}{|l|l|l|l|l|l|l|}
\hline & $\begin{array}{l}\text { Active } \\
\text { site } \\
(\mathrm{mmol})\end{array}$ & $\begin{array}{l}\mathrm{DMNP} \\
(\mathrm{mmol})\end{array}$ & $\begin{array}{l}\mathrm{H}_{2} \mathrm{O} \\
(\mathrm{mmol})^{\mathrm{a}}, \\
0 \mathrm{wt} \%\end{array}$ & $\begin{array}{l}\mathrm{H}_{2} \mathrm{O} \\
(\mathrm{mmol}), \\
40 \mathrm{wt} \%\end{array}$ & $\begin{array}{l}\mathrm{H}_{2} \mathrm{O} \\
(\mathrm{mmol}), \\
100 \mathrm{wt} \%\end{array}$ & $\begin{array}{l}\mathrm{H}_{2} \mathrm{O} \\
(\mathrm{mmol}), \\
400 \mathrm{wt} \%\end{array}$ \\
\hline UiO-66 $(5 \mathrm{mg})$ & 0.0171 & 0.0056 & 0.0127 & 0.124 & 0.290 & 1.124 \\
\hline UiO-66-NH $\mathrm{NH}_{2}(5 \mathrm{mg})$ & 0.0061 & 0.0056 & 0.0317 & 0.143 & 0.309 & 1.143 \\
\hline NU-1000 $(5 \mathrm{mg})$ & 0.0092 & 0.0056 & 0.0126 & 0.124 & 0.290 & 1.124 \\
\hline
\end{tabular}

${ }^{\mathrm{a}} 0 \mathrm{wt} \%$ water loading was calculated based on the amount of water present in the MOFs under ambient condition $(\sim 20 \% \mathrm{RH})$.

Table S3. The number of moles of catalyst active sites, adsorbed water, and agents used for solidphase decontamination of GD and VX by UiO-66, UiO-66- $\mathrm{NH}_{2}$, and NU-1000 under different RH conditions.

\begin{tabular}{|l|l|l|l|l|l|l|l|}
\hline & $\begin{array}{l}\text { Active } \\
\text { site } \\
(\mathrm{mmol})\end{array}$ & $\begin{array}{l}\mathrm{GD} \\
(\mathrm{mmol})\end{array}$ & $\begin{array}{l}\mathrm{VX} \\
(\mathrm{mmol})\end{array}$ & $\begin{array}{l}\mathrm{H}_{2} \mathrm{O} \\
(\mathrm{mmol}), \\
20 \% \mathrm{RH}\end{array}$ & $\begin{array}{l}\mathrm{H}_{2} \mathrm{O} \\
(\mathrm{mmol}), \\
40 \% \mathrm{RH}\end{array}$ & $\begin{array}{l}\mathrm{H}_{2} \mathrm{O} \\
(\mathrm{mmol}), \\
60 \% \mathrm{RH}\end{array}$ & $\begin{array}{l}\mathrm{H}_{2} \mathrm{O} \\
(\mathrm{mmol}), \\
80 \% \mathrm{RH}\end{array}$ \\
\hline UiO-66 $(10 \mathrm{mg})$ & 0.0342 & 0.0112 & 0.0075 & 0.0254 & 0.226 & 0.262 & 0.280 \\
\hline UiO-66- $\mathrm{NH}_{2}(10 \mathrm{mg})$ & 0.0122 & 0.0112 & 0.0075 & 0.0634 & 0.1476 & 0.1598 & 0.1692 \\
\hline NU-1000 $(10 \mathrm{mg})$ & 0.0184 & 0.0112 & 0.0075 & 0.0252 & 0.0504 & 0.1334 & 0.828 \\
\hline
\end{tabular}



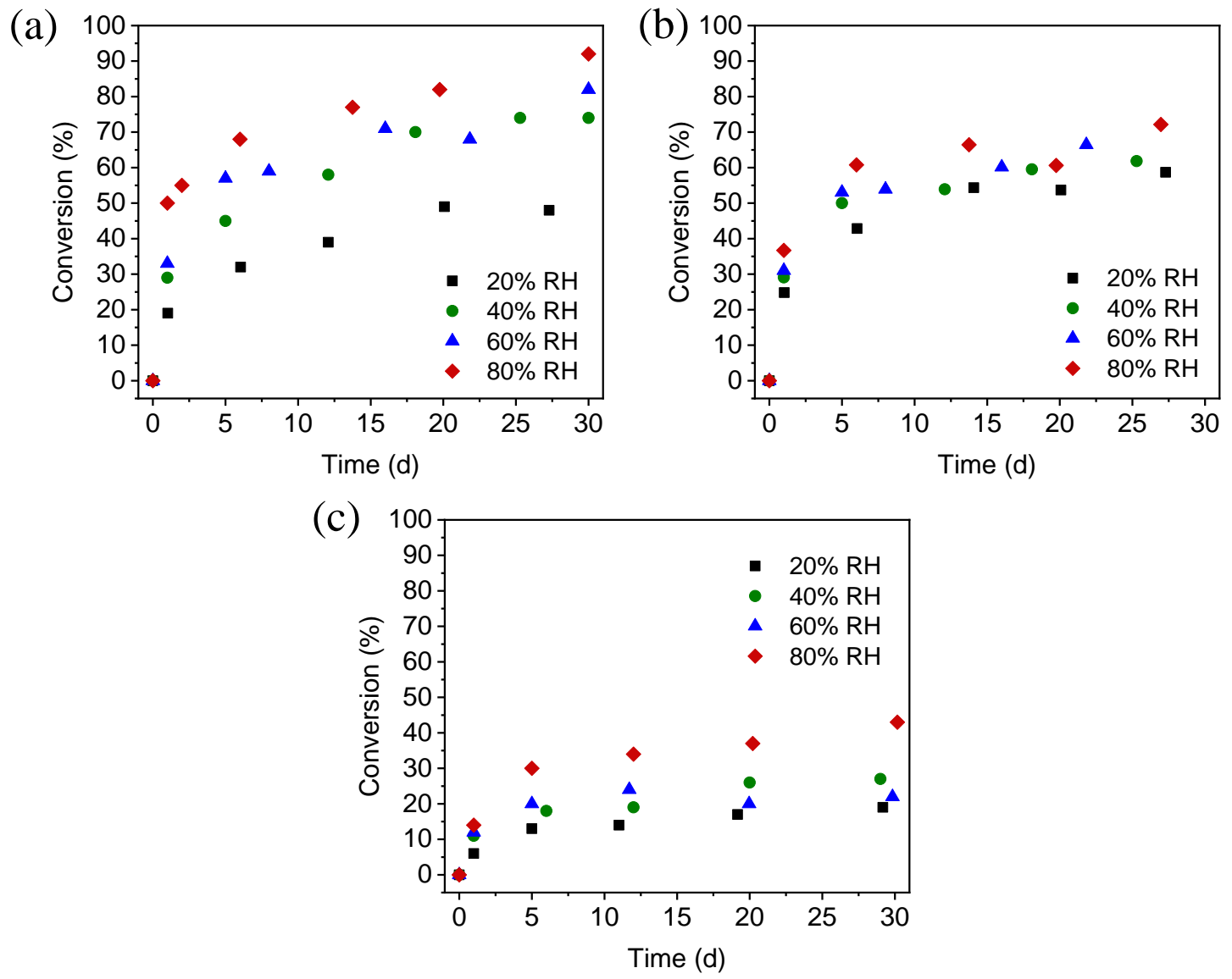

Figure S13. Conversion profiles of DMNP by (a) UiO-66, (b) UiO-66- $\mathrm{NH}_{2}$, and (c) NU-1000 under different RH conditions.

a)

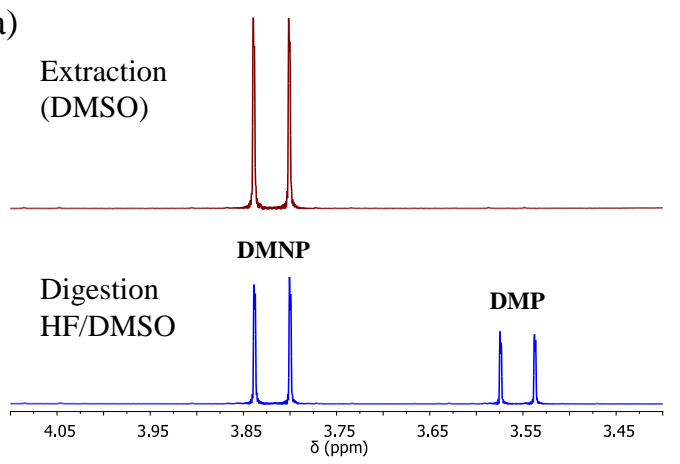

b)

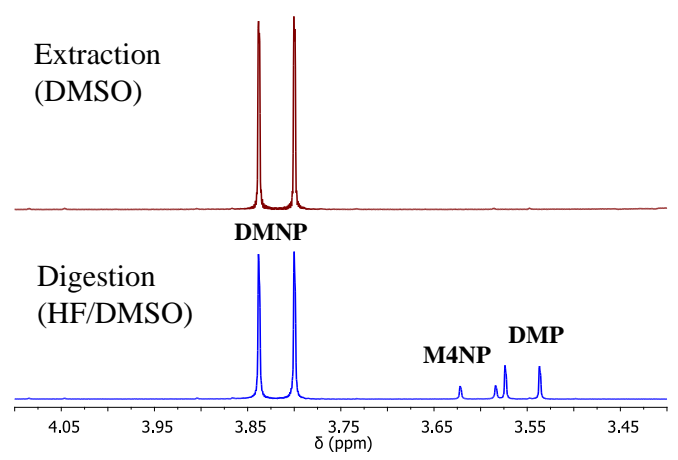

Figure S14. Comparison of extraction and digestion methods for analyzing solid-phase hydrolysis of DMNP (24 h incubation, $40 \% \mathrm{RH}$ ) on a) UiO-66 and b) UiO-66- $\mathrm{NH}_{2}$. No phosphate products were detected by extracting the reaction mixture with $\mathrm{DMSO}-\mathrm{d}_{6}$, suggesting the strong binding of phosphate products to the $\mathrm{Zr}$ nodes. 
Section S4. Solution Decontamination of DMNP by UiO-66, UiO-66-NH $\mathrm{N}_{2}$ and NU-1000
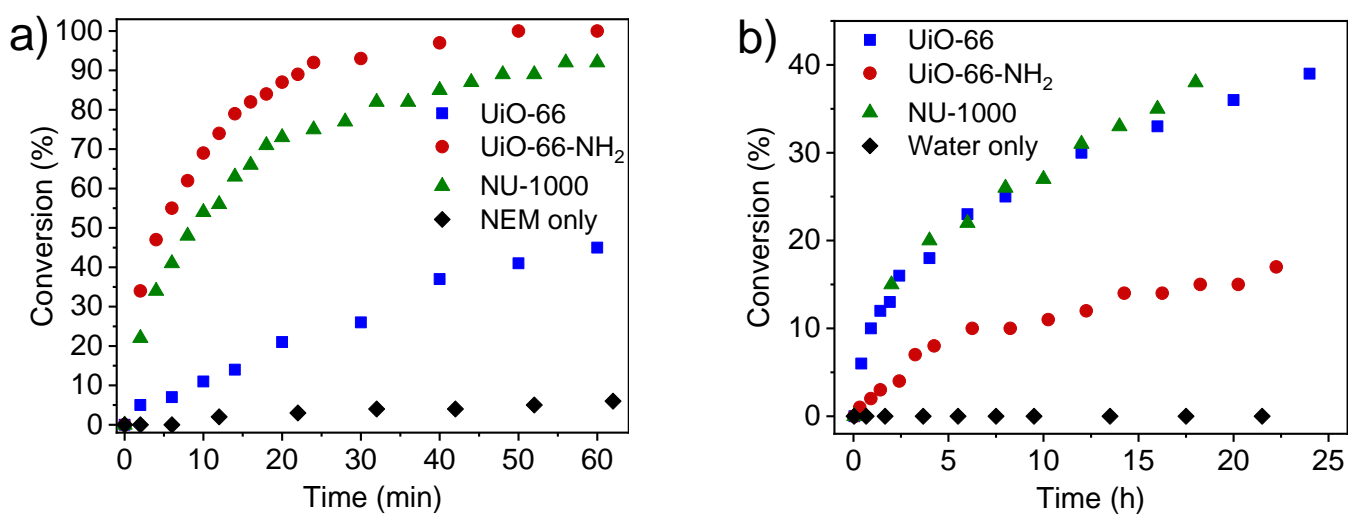

Figure S15. Conversion profiles of DMNP by Zr-MOFs in a) $0.45 \mathrm{M}$ N-ethylmorpholine aqueous solution and b) distilled water. 
Section S5. ${ }^{1}$ H NMR Spectra

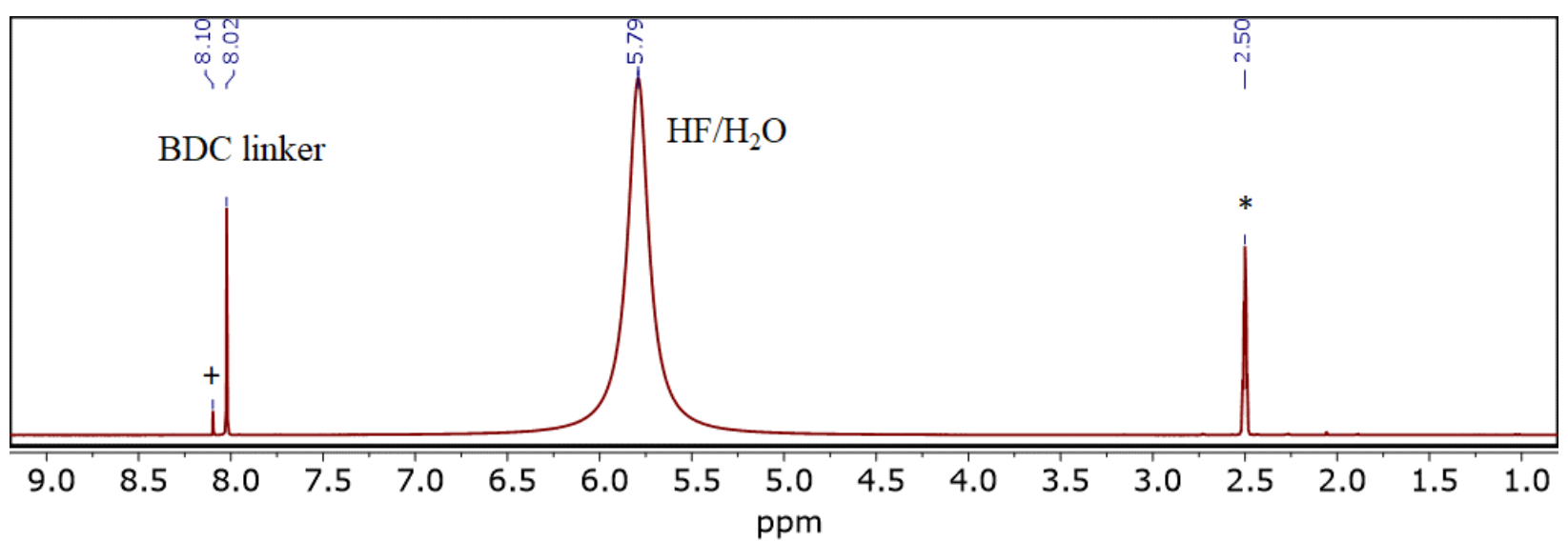

Figure S16. ${ }^{1} \mathrm{H}$ NMR spectrum of digested UiO-66 in HF/DMSO-d 6 . DMSO (*), formic acid (+).

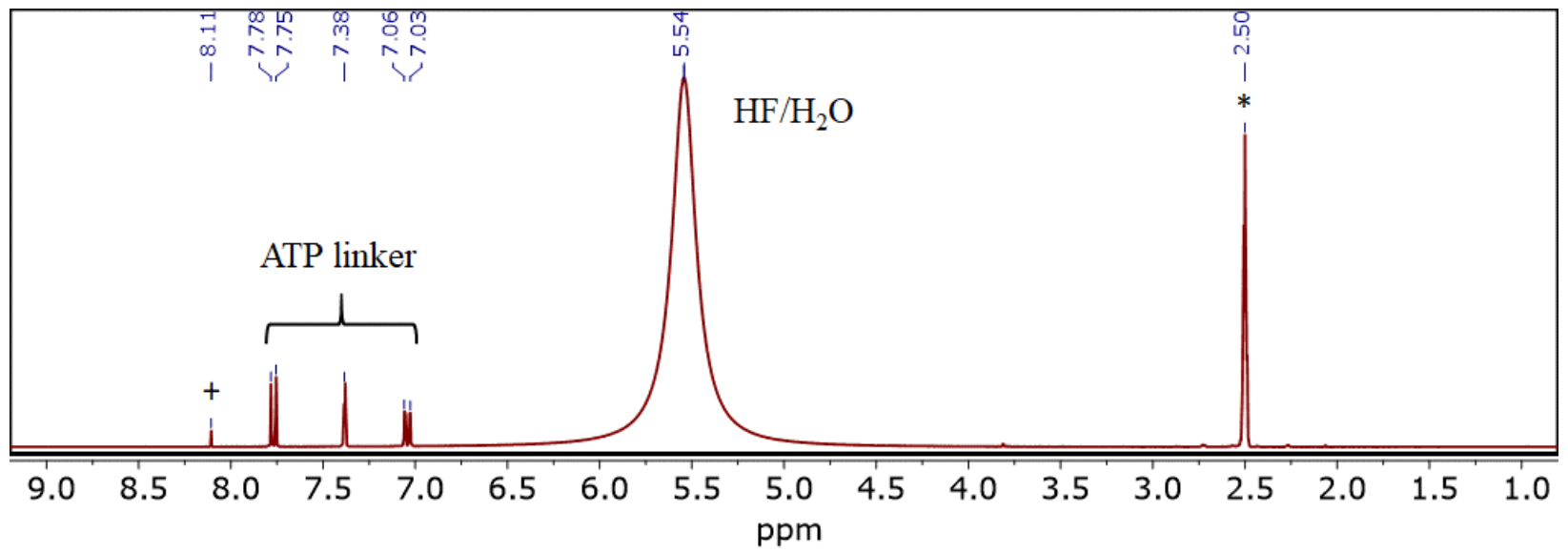

Figure S17. ${ }^{1} \mathrm{H}$ NMR spectrum of digested UiO-66- $\mathrm{NH}_{2}$ in $\mathrm{HF} / \mathrm{DMSO}-\mathrm{d}_{6} . \mathrm{DMSO}(*)$, formic acid (+). 


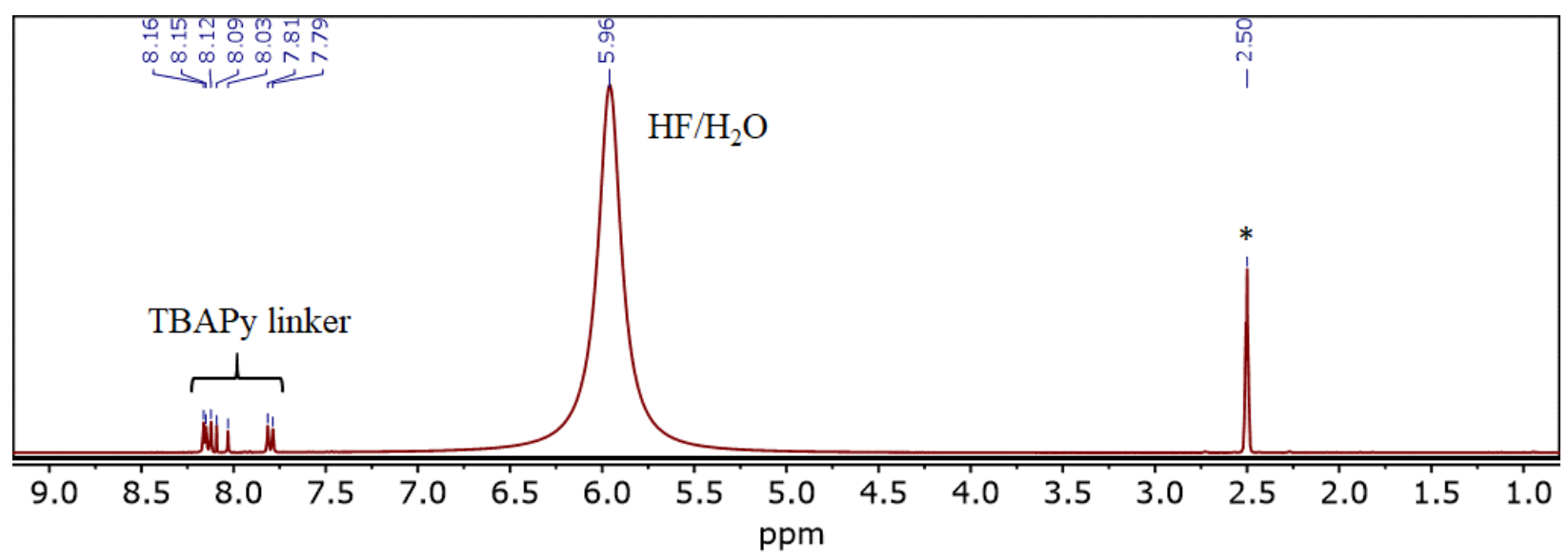

Figure S18. ${ }^{1} \mathrm{H}$ NMR spectrum of digested NU-1000 in HF/DMSO-d 6 . DMSO (*).

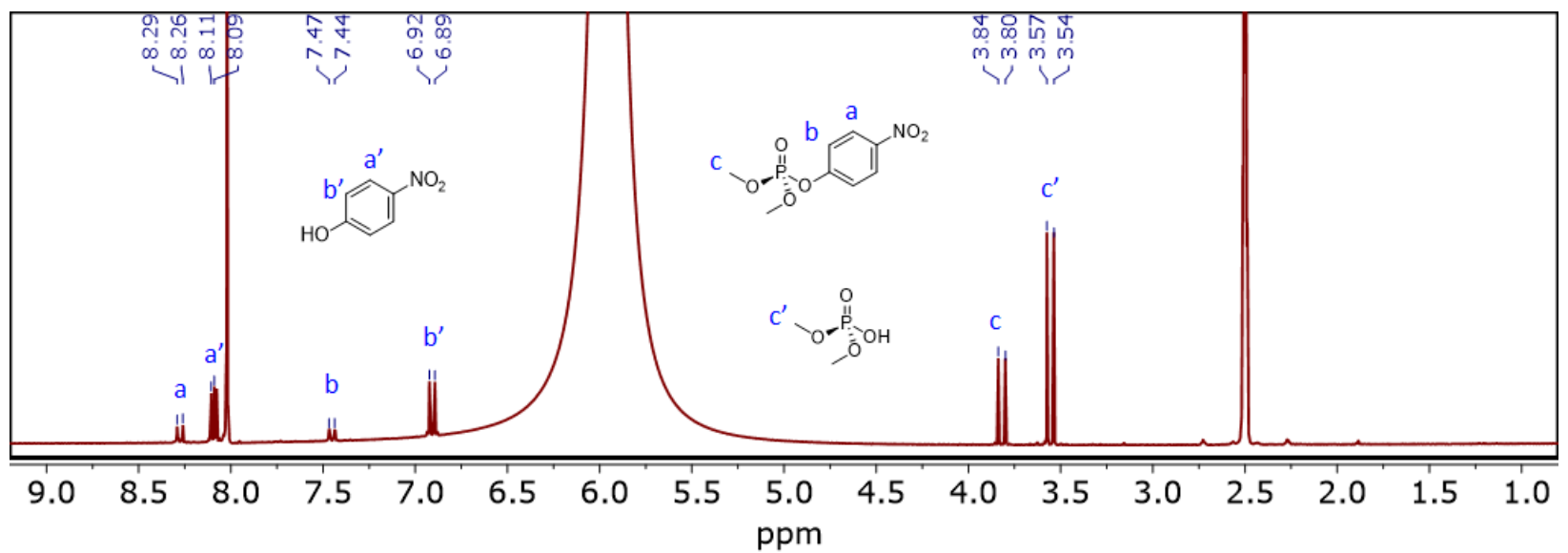

Figure S19. Selected ${ }^{1} \mathrm{H}$ NMR spectrum showing the solid-phase decontamination products of DMNP by UiO-66 after digested with HF/DMSO-d ${ }_{6}$. 


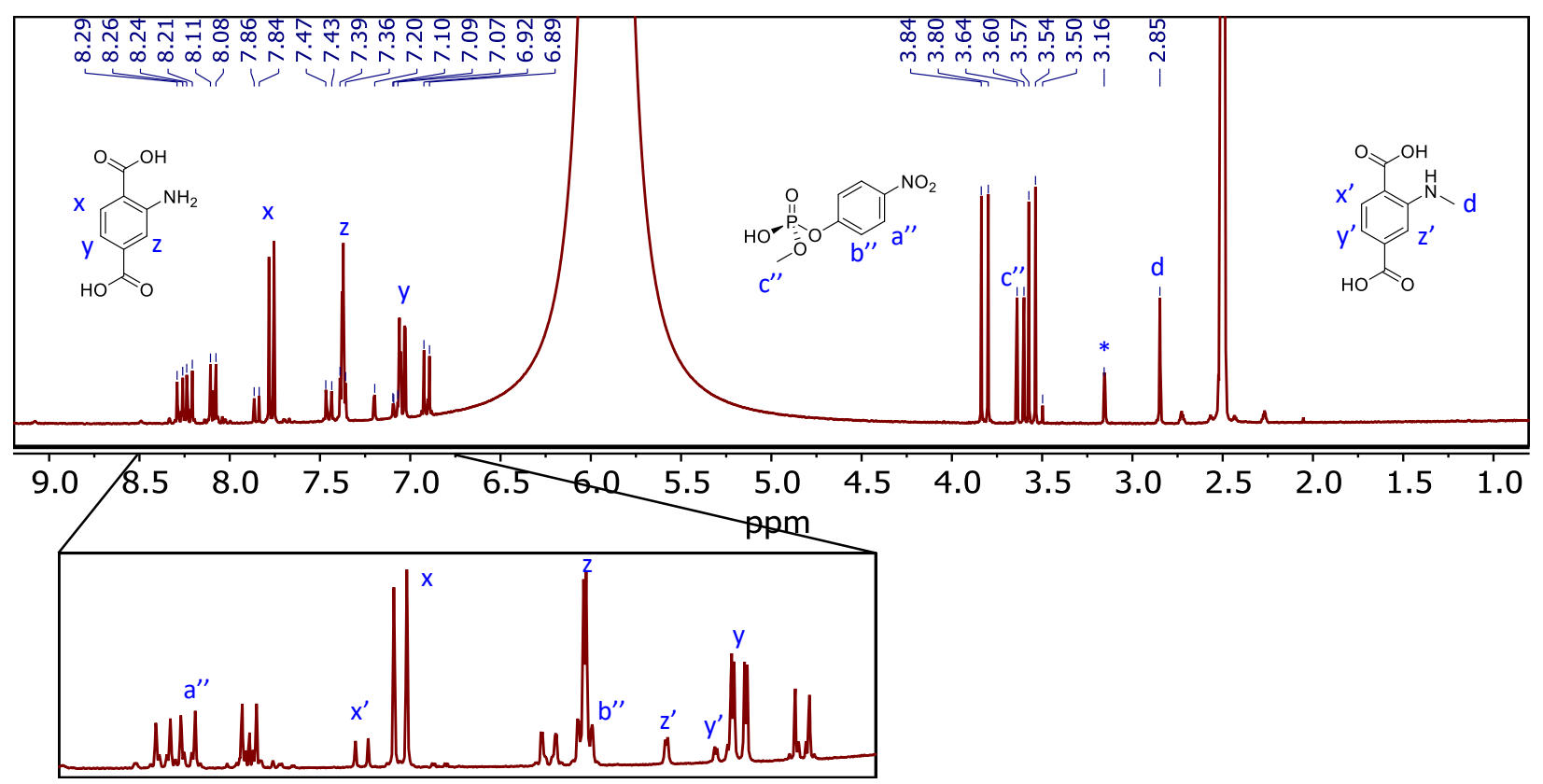

Figure S20. Selected ${ }^{1} \mathrm{H}$ NMR spectrum showing the solid-phase decontamination products of DMNP by UiO-66- $\mathrm{NH}_{2}$ after digested with $\mathrm{HF} / \mathrm{DMSO}-\mathrm{d}_{6} . \mathrm{MeOH}(*)$.

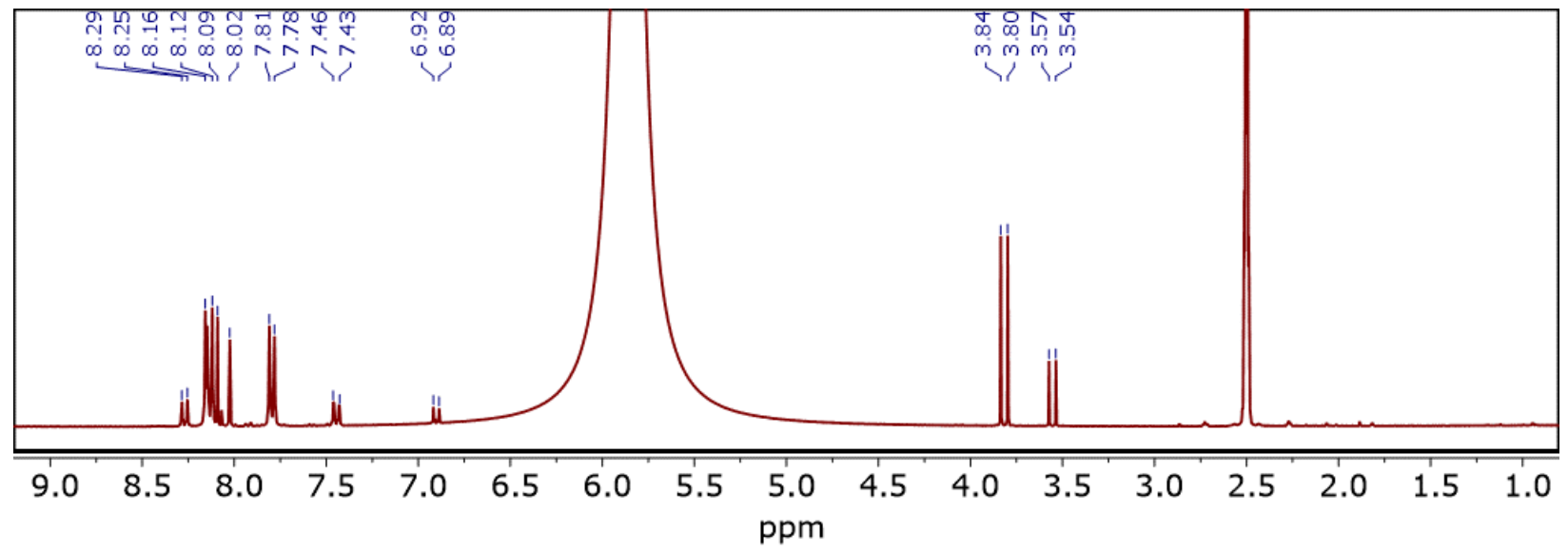

Figure S21. Selected ${ }^{1} \mathrm{H}$ NMR spectrum showing the solid-phase decontamination products of DMNP by NU-1000 after digested with HF/DMSO-d 6 . 


\section{Section S6. Reference}

1. Shearer, G. C.; Chavan, S.; Bordiga, S.; Svelle, S.; Olsbye, U.; Lillerud, K. P. Defect Engineering: Tuning the Porosity and Composition of the Metal-Organic Framework UiO-66 via Modulated Synthesis. Chem. Mater. 2016, 28, 3749-3761. 